\title{
Narrative, Self-Realization, and the Shape of a Life
}

\author{
Samuel Clark ${ }^{1}$ (D)
}

Accepted: 26 March 2018 / Published online: 14 April 2018

(C) The Author(s) 2018

\begin{abstract}
Velleman, MacIntyre, and others have argued for the compositional view that lives can be other than equally good for the person who lives them even though they contain all and only the same moments, and that this is explained by their narrative structure. I argue instead for explanation by self-realization, partly by interpreting Siegfried Sassoon's exemplary life-narrative. I decide between the two explanations by distinguishing the various features of the radial concept of narrative, and showing, for each, either that self-realization is just as good an account, or that we should prefer the self-realization account, of the composition it is supposed to explain. I conclude that, if the shape of a life matters, it matters because some shapes are self-realizations, not because they are narratives.
\end{abstract}

Keywords Well-being $\cdot$ Shape of a life Narrative $\cdot$ Autobiography $\cdot$ Siegfried Sassoon

\section{Introduction}

In this paper I argue against taking narrative as central to the 'shape of a life' phenomenon in value theory, partly by interpreting one exemplary life-narrative, Siegfried Sassoon's Memoirs of George Sherston (1937). My aims are: first, to understand the evaluation of temporally-extended human lives as going well or badly. Second, to disambiguate one out of the various putative roles of autobiographical narrative in a cluster of problems about value, the self, and the interpretation of human lives over time. Third, by showing that narrative does not play that particular role, to advance by one step a general project of critique of the use of autobiographical narrative in that cluster of problems. I begin by introducing my central case.

Samuel Clark

sam.clark@lancaster.ac.uk; http://www.lancaster.ac.uk/ppr/about-us/people/sam-clark

1 Department of Politics, Philosophy, and Religion, Lancaster University, County South, Lancaster LA1 4YL, UK 


\section{Sassoon}

Siegfried Sassoon was born in 1886 into materially comfortable but socially uneasy circumstances: his mother Theresa was from the artistic, socialist, but impeccably establishment Thornycroft family; his father Alfred was a younger son of the Jewish banking and trading dynasty founded in the early nineteenth century, in Baghdad, by Siegfried's great-grandfather David Sassoon. Siegfried's parents separated in 1890, and Alfred died of tuberculosis in 1895.

Sassoon moved in aristocratic and artistic circles, but was always aware - and sometimes complicit in - their currents of anti-Semitism and of snobbery about people who had made their money in trade. He was intrusively self-conscious, self-doubting, and partly alien, and he most admired people he saw as singleminded, straightforward, and fully at home.

Sassoon is now remembered as one of the poets and autobiographers of the trenchesalongside Wilfred Owen, Robert Graves, Isaac Rosenberg, Edmund Blunden, Edward Thomas ${ }^{1}$ - who helped to define our default understanding of World War I: lions led by donkeys, mud and blood at the Somme, walking in disciplined ranks into machine-gun fire, the absurd death of Edwardian England. ${ }^{2}$

But — unlike Owen, Rosenberg, or Thomas - Sassoon had a long post-war life as a public figure, a poet, and an autobiographer. That last role is my interest here: I focus on Sassoon's Memoirs of a Fox-Hunting Man (first published in 1928), Memoirs of an Infantry Officer (first published in 1930), and Sherston's Progress (first published in 1936). This slightlyfictionalized autobiographical trilogy is Sassoon's definitive dramatization of a selfinterpretation common to many soldiers: from innocence to experience via war's baptism of fire. In Sassoon's telling: from a pre-war idyll of private income, golf and village cricket, horseriding in hunts and steeplechases, intense friendships with other young men, and privatelyprinted editions of his sentimental and old-fashioned verse; to the adventure, misery, comradeship, and loss of the trenches, his lightly-touched on heroism (he won a Military Cross), his equivocal revolt against the war, and the wide publication and recognition of realistic and satirical poems like 'To Any Dead Officer', 'Survivors', and 'The General':

'He's a cheery old card,' grunted Harry to Jack

As they slogged up to Arras with rifle and pack.

*

But he did for them both by his plan of attack.

(Sassoon 1984: 69)

And through that experience to a transformed adult selfhood which looks back on pre-war innocence as another life, lived by someone else.

\section{The Shape of a Life}

The question at stake in the shape of a life debate is: what is the relation between the goodness of moments or parts of a human life and the goodness of the whole

\footnotetext{
${ }^{1}$ Kendall (2013) is one of many anthologies of the poetry. The autobiographies, apart from Sassoon's, include Blunden (2000) and Graves (2000).

${ }^{2}$ Anyone who knows Blackadder Goes Forth knows this default. See further Fussell (2000), Winter (1995), and, for argument that this picture of the war is largely wrong, Sheffield (2001).
} 
temporally-extended life from beginning to end? The goodness this asks about is specifically goodness for the person whose life it is: that particular value which is the object of self-interested concern. ${ }^{3}$ We can get an intuitive handle on it by asking what we want, or what we rationally should want, for those we care about-including ourselves (Feldman 2004; Darwall 2002).

As David Velleman puts the question about the shape of a life, 'is the good life just a string of good years?' (Velleman 2000: 57). To see why we might think not, here is my version of a popular thought experiment. Consider two lives: Siegfried Sassoon's life of innocence transformed into experience; and his counterpart Sassoon Siegfried's life, which is a disordered 'sprawl of incidents' (Lessing 1995: 202), one damn thing after another, with no overall shape or organizing telos. Assume that these two lives instantiate the exact same set of momentary goods and bads: that the only difference between them is the temporal ordering of those moments (compare Brännmark 2001: 226; Dorsey 2015: 304-5; O’Neill 2008: 136, ${ }^{4}$ Slote 1983: 23-4, Velleman 2000: 589). This is an intuition pump for the thought that we should evaluate these lives differently as wholes, just because of their 'shape' over time. We might judge that Siegfried Sassoon's life goes better overall than Sassoon Siegfried's, but nothing I say here depends on that particular evaluation. The claim I need is only that lives can be other than equally good even though they contain all and only the same moments. I have no brief here to rank-order particular real or imaginary lives: my concern is the meta-level problem of explaining the relevance of temporal shape.

The conclusion we are supposed to draw from two lives is that overall goodness is not equal to the sum of momentary goods and bads. In evaluation of whole-life goodness, moments are not prior, either because the whole is prior and moments only have a value in that context, ${ }^{5}$ or because they are distinct kinds of evaluation with no relation of priority either way. ${ }^{6}$

Call views that temporal shape matters for evaluation in this way compositional views, and the value-property they pick out composition (I take the term from Brännmark 2001). Compositional views of one kind or another are held by Alasdair MacIntyre (2007), David Velleman (2000), John O’Neill (2008), and Michael Slote (1983). Non-compositional or anti-compositional views - sometimes called additive or summative or time-neutral views - are held by Fred Feldman (2004), Thomas Nagel (1979), John Rawls (1999), and Henry Sidgwick (1981).

For my purposes here I am going to assume the truth of some compositional view and ask: given that temporal shape matters, why does it? What explains the putative fact that the shape of a life makes a difference to how well it goes for the person whose life it is?

\footnotetext{
${ }^{3}$ This value is variously labelled well-being (Griffin 1986), welfare (Darwall 2002), prudential value (Tiberius 2015), quality of life (Nussbaum and Sen 1993), what makes someone's life go best (Parfit 1986), what is good for a human being (Kraut 2007), or the good life (Carson 2000). I will use 'good', 'goodness', and 'good life', and talk of a life's 'going well', 'going best', and 'going better' (for the person whose life it is), from now on. ${ }^{4}$ I borrow my Siegfried Sassoon/Sassoon Siegfried conceit from O’Neill, whose version of two lives contrasts Orson Welles with Welles Orson.

${ }^{5}$ This is not exactly Alasdair MacIntyre's view, since he is concerned with the priority over individual actions of the temporally-extended activities and practices of which they are part, not directly with momentary and wholelife goods (2007: chapter 15). But my version is at least MacIntyrean.

6 This is David Velleman's view.
} 


\section{Narrative}

One popular answer to this question is narrative. Shape matters because how good a person's life is depends in some way on its being a story and/or on what kind of story it is. Velleman, for example, says that:

Intuitively speaking, the reason why well-being isn't additive is that how a person is faring at a particular moment is a temporally local matter, whereas the welfare value of a period in his life depends on the global features of that period. More specifically, the value of an extended period depends on the overall order or structure of events - on what might be called their narrative or dramatic relations. (Velleman 2000: 58)

Velleman then elaborates these relations as events 'lending and borrowing different meanings in exchange with preceding events' (Velleman 2000: 64). John O'Neill, similarly, moves directly from his version of two lives to an appeal to narrative:

The life of Welles Orson goes better than that of Orson Welles. This is true even if all the good moments in the life of Orson Welles are equally as pleasurable as all the good moments in that of Welles Orson and all bad moments are equally as bad so that the total hedonic value is identical. It does so in virtue of the narrative structure of the life. (O’Neill 2008: 136)

This answer has its attractions: it is tempting to say that what makes the difference between my two lives is that Siegfried Sassoon's life has a plot, a coherent and satisfying narrative arc held together by connections like causation, foreshadowing, and ironic contrast. Sassoon Siegfried's life lacks that. The events in Siegfried Sassoon's life make mutual sense of one another, where Sassoon Siegfried's life is 'a sort of Humean froth, a meaningless fluttering on the surface of life' (Sacks 1986: 37).

Despite these attractions, I think the narrative answer is a mistake. My plan against it is in three parts: first I define narrative, in order to make space, second, to display some possible non-narrative explanations of composition. Third, I argue against the narrative explanation and for an alternative explanation by self-realization.

So, first:

A narrative is a generic telling of a connected temporal sequence of particular actions taken by, and particular events which happen to, agents. ${ }^{7}$

These various features need not appear together; many of them are not individually necessary for something's being a narrative; and several sub-groups of them are sufficient for its being so. This is because narrative is a radial category (Lakoff 1987), with clear central or paradigmatic cases - George Eliot's realist novel Middlemarch (1997), Antony Beevor's military history D-Day (2010), Richard Holmes's literary biography Shelley (1976)—and chains of similarity and extension, from one of their typical features or another, leading out to cases-by-association and ambiguous cases. Narrativity is therefore a matter of degree, not all-or-nothing, and different cases can be equally narrative in different ways. Or consider narratives of geological processes, or of the formation of the solar system, or of the first few microseconds after the big bang.

\footnotetext{
${ }^{7}$ My definition differs somewhat from the definitions given by Gregory Currie (2010) and by Peter Goldie (2012): Currie is more concerned than I am with the way in which narrative tellings represent their contents by manifesting their makers' communicative intentions; Goldie focusses on the product of narration (a story) where I focus on the process (a telling). I do not believe that these are significant differences for my purposes.
} 
So, for example, there are narratives which are not yet generic, because they help to found the genres in which they can later, anachronistically, be placed: consider Frankenstein's relation to science fiction. Further out from the centre, there are perhaps agentless narratives. In film, consider Koyaanisqatsi (Reggio 1982) or Fiorucci Made Me Hardcore (Leckey 1999), which merely tell a temporal sequence of visual and auditory events with relations of analogy, contrast, and repetition within a rhythmic structure, and which contain images of human beings, alongside other objects, without representing their agency.

But there are limits to the extent of these chains: not everything is a narrative, because being a telling is a necessary condition of being one. There are no non-artefactual narratives. The existence of a narrative requires the narration of some content to which it refers, and which need not itself be a narrative. We can tell stories about stories - consider One Thousand and One Nights - but not all stories are about stories. Some are about fox-hunting and fighting in the trenches.

The flip-side of that point is that being a temporal sequence of particular actions and events is not sufficient for being a narrative. There are innumerable untold sequences - consider 'what happened at exactly the grid reference you are at now, in the 24 hours leading up to exactly 1,000 years ago' - which are presumably narratable, but which aren't narratives until told. Many temporal sequences of actions and events are potential content for narratives, but not yet narratives.

But how about being a telling of an unconnected temporal sequence of particular actions and events? For example: 'at 2pm yesterday, a schoolgirl in Amsterdam accidentally left her bag on the tram; at 230pm, the President convened a meeting of her national security advisors; at $3 \mathrm{pm}$, a family of swans drifted lazily across Coniston Water...'. This is in a vague borderland, where is this a narrative? is perhaps an empty question, and we should just say that it has some of the features of paradigmatic narratives but not others. If we need a name for it, we could call it an annal (Carroll 2003).

Moving inwards across that borderland, a telling of temporal sequence of particular agents' actions and events connected such that some of them are explained - the schoolgirl forgot her bag because she was worried that when she got home, mum would be drunk again - is more narrative than my example annal.

Getting closer to the centre, a telling of a temporal sequence of particular agents' actions and events connected both by explanatory and by literary relations like analogy, echo, poetic justice, etc. - mum isn't drunk this time, because she's searching desperately for her own lost bag — is still more clearly narrative than my previous example. I suggested above that one of the attractions of the narrative explanation of composition was that some lives are held together by connections like 'causation, foreshadowing, and ironic contrast': we can now see that this list combines two different kinds of connection, the explanatory ${ }^{8}$ and the literary, and that they should be separated.

Back at the centre, a telling of a connected temporal sequence of particular agents' actions and events which create expectations in its audience about what kinds of further actions and events will follow - mum's lost bag contained money she was carrying for a local mob-boss; the next scene is an exhausted detective taking one more call five minutes before she's due to go off shift—has added a generic character (Currie 2004: chapter 3).

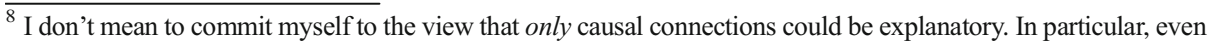
if reasons are not just a variety of cause, agents' reasons may explain their actions - the President convened a meeting of her national security advisors in order to discuss a crisis in the Middle East. But I can remain neutral on this question: all I need is the claim that the literary relations of an actual action or event do not explain its occurrence (although they may explain the teller of a narrative's decision to represent those particular actions and events rather than others).
} 
With this account of narrative in hand, we can say that the most strongly narrative explanation of composition is that temporal shape matters because lives are (or can be) generic tellings of a connected temporal sequence of particular actions taken by, and particular events which happen to, agents - and especially the agent whose life we are talking about. Siegfried Sassoon's life has a different overall goodness from Sassoon Siegfried's because they are different stories (even though both stories consist in an ordering of the same moments), or perhaps because Sassoon Siegfried's life fails to be a story at all.

\section{Non-narrative Explanations of Composition}

Narrative accounts of composition too frequently move directly from an argument that shape over time matters to the further claim that narrative explains why that shape matters, as if that were the only possible explanation, or even as if shape were equivalent to narrative. Having been specific about what a narrative is, and therefore what a narrative explanation for composition would need to be, we can now see both the space for at least four alternative possibilities, and the argumentative gap between shape and narrative explanations of that shape. I don't mean to claim that the alternatives I canvass here are all of the possibilities, just that they are not narrative explanations, but could explain composition.

First, a way of explaining away composition: taking pleasure. Fred Feldman argues that composition is just a special case of his attitudinal hedonist account of the good life. Attitudinal pleasure is the propositional attitude of taking pleasure in, enjoying, or being pleased by some state of affairs, analogous to hoping for or fearing that state of affairs. It is distinct from sensory pleasure, which is just whatever sensations someone takes pleasure in (this neutralizes the standard antihedonist argument that there is no common phenomenology to our various sensory and other pleasures). Attitudinal hedonism is then the view that the good life is the life of attitudinal pleasure (Feldman 2004: chapter 4). The shape of a life then makes a difference to how well that life goes only when the person whose life it is takes pleasure in that shape (Feldman 2004: chapter 6). If she doesn't - if she is unaware of her life's shape because she is caught up in the quotidian, for example - then that shape makes no difference to how well her life goes for her. It may of course please us, the people who do notice, but that is to our good not hers (and this is one of Feldman's repeated moves: to argue that the appearance of non-hedonistic value is caused by our illegitimate projection of ourselves and our own attitudes into the thought experiment). The attitude of taking pleasure in is, like narrative telling, intentional - it is about something, it has directedness towards content to which it refers (Searle 1983) — but it is obviously not a narrative or a narration.

Second, artefactual but non-narrative shape. For example, we can imagine a life with a musical shape, structured by non-causal relations like harmony, contrast, theme and recapitulation, tension and resolution, and balance (these terms will each have to be interpreted more or less metaphorically). A life so shaped could be a performance (if it was so shaped on purpose), but not a narrative, because music is not intentional: it isn't about anything, it isn't directed towards content to which it refers, and it is therefore not a telling. ${ }^{9}$

\footnotetext{
${ }^{9}$ More precisely: music can be about something, but need not be - compare the fourth movement of Beethoven's Pastoral Symphony, which is about a thunderstorm, with his Thirteenth String Quartet, which has no programmatic content. Or compare the Stan Tracey Quartet's Under Milk Wood, which is about Llareggub (or perhaps about Dylan Thomas's poem) with Miles Davis's In a Silent Way. I find it harder to think of similarly contrasting pieces of rock or pop music, which may suggest that these kinds of music are distinctively—although vaguely_ intentional.
} 
Third, time of life preference. This is Slote's view against Rawls, Nagel, and others who claim that it is a demand of practical rationality that I maximise my good over my whole life without time-preference (Nagel 1979, Rawls 1999; see further Parfit 1986: part II). For example, it would be irrational to prefer a small good tomorrow to a larger good next year, bracketing uncertainty. Slote argues against this that it is practically rational to prefer goods occurring in the 'prime of life' over even much larger goods in childhood or old age (Slote 1983: chapter 1). This is an appeal to the culturally-mediated biological structure over time of a life, not to a narrative of that life. We can tell stories about that structure, and frequently do; but that's just an example of the point already made that many things are potential contents of narratives without themselves being narratives.

Fourth, self-realization, which is my view and which I set out in a separate section, next.

\section{Self-Realization}

On my self-realization view, temporal shape makes a difference because some shapes are selfrealizations and others are failed self-realizations: they map the expression of potential woken and fed by lucky circumstance, or its thwarting. The temporal structure of a human life which governs how well it goes as a whole is analogous to the temporal structure of the life of a tree which governs how well it goes as a whole. For a tree: does it grow from acorn to sapling to spreading ancient oak? Does it wither for lack of water? Is it wired and pruned into a sad, twisted little bonsai? For a human being: does she flower into skilled, independent adulthood? Is she blighted by poverty or illness? Is she constrained and infantilized by a misogynistic culture? For Siegfried Sassoon: is he able to love without shame, or is he compelled by internal and external homophobia to hide and distort his sexuality? Can he reconcile his solitary inwardness with his delight in comradeship and action, or does he remain torn between them? How does his traumatic battlefield education transform him? Again, this possibility appeals to a narratable structure over time, but not to a narrative.

More abstractly, the self-realization account of the good life is that your life goes well for you when, and in the ways that, your particular true self flourishes rather than being undeveloped or crushed or distorted. Equivalently, when, and in the ways that, your latent capacities - both those you have in common with other humans and those which are individual to you - are fully developed and expressed. Equivalently, when your life is a process of successful growth out of your individual potential into actuality. Your life goes badly for you when, and in the ways that, your common and individual capacities are crushed, distorted, or left fallow.

This self-realization account has historical roots in German Romantics including Goethe and Herder; British Romantics including Wordsworth and Coleridge; and American transcendentalists including Emerson, Thoreau, and Whitman (Lockridge 1989); in Marx (as read by Elster 1989); in Nietzsche (1997, 2007); in Mill (as read by Clark 2010); and in post-Freudian psychologists including Jung, Maslow, and Fromm (Lockridge 1989: 120-121). In recent professional philosophy, Alan Gewirth (1998) and David Norton (1976) have each defended related accounts. Charles Taylor (1991) has discussed a contemporary ideal of individual selffulfillment similar to self-realization. But I am developing my own account, not committing myself to any master or tradition.

The self-realization account is clearly similar to perfectionist accounts (Hurka 1993) on which you have a good life when you actualize your essential humanity; when you fully develop your latent human capacities and thereby live the life of a human being; when you 
fully engage in what humans do which makes them what they are. But self-realization is distinct from perfectionism: perfectionism says that the good life is the one in which you realize essential human potential; self-realization says that it is the one in which you realize individual potential, at least some of which will also be common potential in the sense that other individuals' potentials are similar. That is, different human individuals will both share common human capacities and have their distinctive capacities which are less widely shared or not shared at all. Self-realization for one of us will therefore be in some ways like and in other ways unlike self-realization for others, and the good life for me may be importantly different from the good life for you, or her, or him. ${ }^{10}$

I have offered the first three alternative views canvassed above mostly to make the point that a specifically narrative explanation of composition is only one possibility among several, and that there is therefore an argumentative gap between acceptance of the shape of a life claim and acceptance of a narrative explanation of it. I now move on to argue for self-realization and against narrative.

\section{Agents, Temporal Sequences, and Composition}

Siegfried's Sassoon's innocence to experience life-shape does compositional work to the extent that we evaluate the goodness of his whole life differently from how we evaluate the goodness of Sassoon Siegfried's whole life. The question I am pursuing is: what explains that fact? In this and the following sections 1 argue for a self-realization answer to it by making use of my radial account of narrative. Once we pull the various conditions of narrativity apart and see how each might be involved in explaining composition, the attraction of a narrative explanation dissolves, and the attraction of a self-realization explanation becomes apparent, in different ways for different conditions. I conclude that we should therefore adopt a selfrealization over a narrative account of composition.

Recall, then, that a paradigmatic narrative is a generic telling of a connected temporal sequence of particular actions taken by, and particular events which happen to, agents. What exactly about narrative is supposed to do the compositional work? I shall go through its various features in reverse order.

Is the compositional work done by the fact that narratives involve agents? No: even assuming that a connection can be found between agency and composition over time, this feature fails to distinguish between narrative and self-realization explanations. Loss of innocence is something that happens to an agent, Siegfried Sassoon, on either account. The appeal to agency therefore offers no support to a distinctively narrative explanation of composition.

In that case, is the compositional work done by the fact that narratives are of connected temporal sequences of actions and events? It's tempting immediately to reply 'no' again, for the same reason that self-realization equally involves such sequences, and that this feature therefore also fails to distinguish between narrative and self-realization explanations. But that reply is too quick. Paradigmatic narrative connects its temporal sequences not only by explanation, but by what I have called literary relations: analogy, echo, poetic justice, etc. Siegfried Sassoon's life-narrative connects his careless courage as a rider pre-war with his suicidal courage in the trenches, not only as an explanation of the latter, but through Sassoonas-narrator's later ironic grasp of what his innocent pre-war self could not know. Perhaps, then,

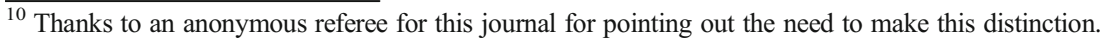


temporal sequences of actions and events connected by specifically literary relations do the compositional work? Velleman's 'lending and borrowing different meanings in exchange with preceding events' $(2000,64)$ could be taken as a version of this possibility.

The problem with that thought is that the literary relations are projected by the narrative's telling, not already there in what the telling is a telling of. Sassoon's irony is a product of his narration of his story, not something there to be discovered in the content he tells us about. In general, literary relations are secondary qualities, in the relation between narrator and what's narrated, not in what's narrated alone. This possibility is therefore a disguised appeal to a different feature of narrative: telling.

\section{Telling and Composition}

So is telling what's important here? Is it that Sassoon tells his life-story as innocence to experience that does the compositional work? This is a more promising thought. Several accounts of the good life appeal to the subject's own judgements or attitudes about her life. ${ }^{11}$ Narrative telling of a life involves a relation to that life; autobiographical narrative telling involves a specifically reflexive relation; and perhaps that relation constitutes the life's compositional good.

I don't think this appeal to telling works either, because it conflates two distinct roles which someone could take up with respect to a life: call them the storyteller and the judge. They are alike in being distanced, third-personal stances, even when reflexive. The attention of the autobiographer to her own life involves separation of self from self, turning her attention as subject on her temporally-extended life as object, in the same way as she might turn her attention on a life which is not hers (Pascal 1960; Goldie 2012). But these roles are importantly distinct: the storyteller gives an account of meaning; the judge gives an account of goodness, of how well the life goes.

Meaning and good are distinct in three related ways. First, I can have a life which is meaningful and which goes badly for me. I can have a life which is meaningful because it goes badly for me: consider Robert Falcon Scott, or Anne Frank, or anyone whose life stands as a horrible warning. These are highly meaningful lives exactly because they are disasters for those who live them.

Second, meaning and good are relativized differently. The meaning of Siegfried Sassoon's life is its meaning to someone who tells his story: Sassoon himself, his various biographers including Max Egremont (2004) and Jean Moorcroft Wilson (2013), the novelist Pat Barker in her Regeneration (1991), me in my section introducing him above, or others. But the good of Sassoon's life is its good for Sassoon himself. Unlike meaning, it is necessarily relativized to the person whose life is good or not. If we talk of the good of Sassoon's life for someone else-for Robert Graves, say—we are talking about instrumental good—Sassoon's usefulness to Graves - not the prudential good we were looking for.

Third, and as a result of its distinctive relativization, meaning can be multiple without contradiction, when relativized to different storytellers. There are many myths of Scott of the Antarctic, for example:

\footnotetext{
${ }^{11}$ I have already described Feldman's attitudinal hedonism. We could add L. W. Sumner's (1996) authentic lifesatisfaction account and second-order desire accounts deriving from Harry Frankfurt (e.g. Frankfurt 2006).
} 
In the post-war anomie of the 1920s, Apsley Cherry-Garrard published his memoir of the expedition, The Worst Journey in the World, as a lament for 'an age in geological time, so many hundreds of years ago, when we were artistic Christians' ... The 1930s saw the expedition's concern with natural history fashioned into something congruent with Tarka the Otter and rambling in shorts. The 1948 film Scott of the Antarctic, with John Mills as Scott, shaped it as a post-war fable of class integration, apt for the austerity era. The myth had a quiescent period in the 1950s and 1960s, when it held a secure if shrunken position as a perfectly typical subject for a Ladybird book for children. But it metamorphosed, rather than died, on the publication of Roland Huntford's debunking biography Scott and Amundsen ... Huntford denounced Scott from the New Right, as an example of the sclerotic official personality; the playwright Trevor Griffiths, adapting Huntford's book as a TV drama, attacked Scott from the Left as a representative of privilege and the Establishment bested by a rather democratic, workmanlike set of Scandinavians. (Spufford 1996: 4-5)

Similarly, Sassoon's life has meant different things to his various storytellers. Egremont takes Sassoon's life to illuminate a particular relation to an imaginary country: 'Sassoon evokes a lost, decent England achieved only in the imagination, perhaps only in the imaginations of those a little outside this county of the heart' (Egremont 2004: 524). For Barker, Sassoon is one of various mirrors she holds up to the war and to British war culture. Sassoon himself at different times found different meanings in his own life. His later autobiographical trilogy The Old Century (1938), The Weald of Youth (1942), and Siegfried's Journey (1945) give different significance to the same actions and events as the earlier Memoirs of George Sherston: Sassoon repudiates his 1917 protest against the conduct of that war in light of his support for war against Nazi Germany, for example.

To be clear, I do not mean to claim that anything goes in meaning-finding, only that the standards which do apply - accuracy and sincerity, say (Williams 2002) —underdetermine what meanings one can properly find in a life, and that this is not a problem for storytellers. Meaning is happily plural.

The good, in contrast, cannot be multiple without contradiction, because the goodness of a life supervenes on the life: there are no pairs of possible worlds such that both contain Sassoons identical in every way except that one's life goes badly and the other's goes well (I don't mean this claim to imply or require any heavy meta-ethical lifting).

With those distinctions between meaning and good in place: telling does the storyteller's meaning-finding or meaning-making work, not the judge's good-evaluative work, including the specific evaluation of compositional good over the whole life. Narrative telling therefore fails to explain composition, although it perhaps does explain meaning.

What about self-realization? My point in this section is that composition is not explained by telling, and is therefore a fortiori not explained by reflexive telling, by telling one's own story. And I want to generalise that point: one's whole-life good is not constituted by any reflexive relation to one's life — not the relation of telling it nor, for example, the relations of enjoying it or endorsing it. Whatever it is that makes my life good or bad as a whole is in the life, not in any attitude or judgement or other relation I take to that life. Composition is a primary not a secondary quality of a life. If that's right, the explanation of composition will have to appeal to some structure in the life, rather than one projected on to it or constructed in reaction to it. And the self-realization explanation of composition does appeal to such a structure: the growth of the self over time. So, although this doesn't show that self-realization is the uniquely correct 
explanation of composition - there may well be other candidate explanations which meet this condition that the structure must be in the life - it does show that self-realization is a better explanation of composition than narrative.

\section{Genre and Composition}

Finally, does genre explain composition ${ }^{12}$ ? Sassoon's autobiography belongs to a recognizable genre, the martial disillusionment narrative: it is a preeminent example of a standard twentieth-century way of writing about war experience as the burning away of illusion by battlefield education, also adopted by Ernst Jünger (2003), Paul Fussell (1996), ${ }^{13}$ Philip Caputo (1996), and many others. ${ }^{14}$ Perhaps it's that generic shape which does the compositional work and makes Siegfried Sassoon's life more than mere Humean froth.

Again, no: the best of the World War I martial disillusionment narratives, including Sassoon's, are the successful bringing into genre of unprecedented and at first indescribable experience. They do this partly by using precedent form (Sassoon's irony is derived from Thomas Hardy's, for example), but they remake that form to be newly adequate to that new experience of industrialized mass warfare. The experience is prior to the making over into genre.

The point generalizes: battlefield education is one kind of transformative experience. As L. A. Paul $(2014,2015)$ uses the term, a transformative experience is a life-event with two features. First, it is epistemically transformative. Living through a transformative experience provides a kind of knowledge only available by first-personal acquaintance. Only a parent knows what it's like for her to have a child; only those who have fought know what combat is like for them (the claim is not that nothing can be known third-personally about these and other experiences, it's that not everything can be known that way). Second, such an experience is personally transformative. I am a different person after becoming a parent; Sassoon is a different person after his baptism of fire.

Paul's argument is that the fact of transformative experience in human life is a problem for decision theory, because it makes rational expectation impossible. The person facing the decision whether to undergo such an experience - whether to have children, whether to become a soldier, whether to fight - cannot know in advance whether it will be good or bad for her, and therefore cannot make rational plans by trying to maximize the expected value (the probability of an outcome multiplied by its value) of her choices.

I take a different but compatible point from the fact of transformative experience. Sassoon, like many other soldiers, came to understand his own life over time as marked by the transformative experience of combat. His state of innocence is divided from his state of experience by fighting in World War I. That transformative experience is temporally and logically prior to generic narration and to the distinct kind of understanding that generic narration can provide. The experience of combat is an intrinsically first-personal occurrence in time, which one must be present to in order to have it at all. Reporting such experience in a narrative, in contrast, must be later and secondary.

\footnotetext{
12 This is again a MacIntyrean view, if not exactly MacIntyre's view.

${ }^{13}$ Fussell's case is complicated by the fact that he was a brilliant interpreter of others' war memoirs (Fussell 2000) before writing his own.

${ }^{14}$ See Yuval Harari $(2005,2008)$ on the history of this way of making sense of war.
} 
The priority of experience over generic narrative is shown partly by the fact that we can fail adequately to narrate such experience. It is a major artistic achievement when we succeed: compare Sassoon's success with, for example, David Jones's interesting failure in In Parenthesis (1937), which, as Paul Fussell argues, never escapes the precedent mythic forms Jones brings to his attempt to narrate his war experience (Fussell 2000: chapter 4).

Battlefield education, as one of many kinds of transformative experience, is prior to the generic narration of that experience. And, I now add, transformative experience is one kind of self-realization: one way in which we grow is by transformation. As for telling in the previous section, the compositional work is done in the intrinsic structure of the life, not in something we relationally or reflexively do to it, or some stance we relationally or reflexively take up towards it. We may generically tell the stories of the transformative and other self-realizations which shape our lives, because they are more of the many potential contents for narratives. But we need not in order for that self-realization to happen. Self-realization is therefore, again, a better explanation of composition than is narrative genre.

\section{Self-Realization and Composition}

Summing up my argument: the narrative explanation for composition is that temporal shape matters because lives are (or can be) generic tellings of a connected temporal sequence of particular actions taken by, and particular events which happen to, agents - in particular the agent whose life we are evaluating. The self-realization explanation is that temporal shape matters because some shapes are self-realizations: they map the expression of potential woken and fed by lucky circumstance (in Sassoon's and other cases, that waking is jarring and the feeding traumatic). I have compared the two explanations by distinguishing the various features of the radial concept of narrative, and showing, for each, either that self-realization is just as good an account, or that we should prefer the selfrealization account, of the composition it is supposed to explain.

Both explanations can appeal to agents and to temporal sequences of causally connected actions and events. Narrative can further appeal to temporal sequences of actions and events connected by literary relations, but literary relations are projected by narrative telling, not in the actions and events themselves, so this is just a disguised appeal to telling. Telling cannot explain compositional value: the appearance that it might is based on a confusion between the storyteller's finding of unproblematically plural meaning in a life, and the judge's evaluation of its singular goodness for the person who lives it. Goodness is not relational in the way that telling and meaning-finding require, but is in the structure of the life, and self-realization matches that feature where narrative cannot. Finally, genre cannot explain composition either, because the shape of a life can involve transformative experience, which is necessarily prior to its generic narration. Self-realization again matches that feature where narrative cannot.

I want to emphasize a point about self-realization which this comparison brings out: it is not relational, and therefore not, in particular, reflexive (it's not a relation a person has to herself because it's not a relation at all). Someone's degree of self-realization is a first-order feature of her life, the degree to which it in fact develops and expresses her central potentials. And, since self-realization explains composition, this is also the conclusion we should draw about that kind of value: the shape of a life which matters for the goodness of a life considered as a whole is a first-order fact about that life over time, not anyone's attitude to, or judgement about, or other relation to, that life. It is therefore, at least in one sense of a multivalent pair of terms, an objective rather than a subjective matter. 
So, for Siegfried Sassoon: the innocence to experience shape of his life matters for how well that life went overall because it is the particular and partial way in which Sassoon realized his human and individual potential (assuming, as I have throughout, that Sassoon is right to understand his own life in this way). He could have stayed an innocent and an artistic failure, but the transformative experience of war enabled him to express at least part of his nature.

Where does this leave Sassoon's and others' autobiographical narratives? They do not constitute the compositional value of these lives: that's in the self-realizing structure of the life. But that may leave such narratives an important role in the discovery and understanding of composition: Sassoon's telling of his own story may reveal to his readers - and to Sassoon himself - an important way in which his life went well for him, despite its hardships and failures.

\section{Conclusion}

I have argued between the particular and the general. After setting out the shape of a life problem and some possible answers to it, I argued for a self-realization over a narrative explanation of composition in the case of Siegfried Sassoon and of other martial disillusionment narratives. I claim that this conclusion generalizes, and that self-realization, not narrative, explains all cases of composition.

Finally, by making that argument I have advanced, by one step, my most general aim: a project of critique of the use of autobiographical narrative in a cluster of problems about value, the self, and our understanding of human life over time. For all I've said here, there is still plenty that autobiography might do to address that cluster. It might be an important means of self-discovery and self-understanding. It might be involved in identity-making self-interpretation, in self-constitution into moral and legal personhood, in learning virtue by remembering and planning, or in reconciling us to our own lives (respectively: Taylor 1989, Schechtman 1996, Goldie 2012, Rosati 2013). But I have excluded autobiographical narrative from one interesting role: if the temporal shape of a life makes a difference to how well it goes as a whole, it does not do so because that shape is a narrative. The shape of a life matters because some shapes are self-realizations.

Open Access This article is distributed under the terms of the Creative Commons Attribution 4.0 International License (http://creativecommons.org/licenses/by/4.0/), which permits unrestricted use, distribution, and reproduction in any medium, provided you give appropriate credit to the original author(s) and the source, provide a link to the Creative Commons license, and indicate if changes were made.

\section{References}

Barker P (1991) Regeneration. Penguin, London

Beevor A (2010) D-day: the battle for Normandy. Penguin, London

Blunden E (2000) Undertones of war. Penguin, London

Brännmark J (2001) Good lives: parts and wholes. Am Philos Q 38:221-231

Caputo P (1996) A rumor of war. Owl Books, New York

Carroll, N. 2003. 'On the narrative connection' in Beyond aesthetics: philosophical essays. Cambridge:

Cambridge University Press. 118-33

Carson, T. L. 2000. Value and the Good Life. Notre dame: University of Notre Dame Press

Clark S (2010) Love, Poetry, \& the Good Life: Mill's Autobiography \& Perfectionist Ethics. Inquiry 53:565-578 
Currie G (2004) Arts and minds. Clarendon Press, Oxford

Currie G (2010) Narratives and narrators: a philosophy of stories. Oxford University Press, Oxford

Darwall S (2002) Welfare and rational care. Princeton University Press, Princeton

Dorsey D (2015) The significance of a Life's shape. Ethics 125:303-330

Egremont M (2004) Siegfried Sassoon: a biography. Picador, London

Eliot G (1997) Middlemarch ed. David Carroll. Oxford University Press, Oxford

Elster J (1989) Self-realisation in work and politics: the Marxist conception of the good life. In: Elster J, Moene

$\mathrm{KO}$ (eds) Alternatives to capitalism. Cambridge University Press, Cambridge, pp 127-158

Feldman F (2004) Pleasure and the good life. Clarendon Press, Oxford

Frankfurt, H. G. 2006. Taking Ourselves Seriously \& Getting it Right ed. D. Satz. Stanford: Stanford University Press

Fussell P (1996) Doing battle: the making of a sceptic. Little, Brown, Boston

Fussell P (2000) The Great War and Modern Memory. 25 ${ }^{\text {th }}$ anniversary edn. Oxford University Press, New York Gewirth A (2998) Self-Fulfillment. Princeton University Press, Princeton

Goldie P (2012) The mess inside: narrative, emotion, and the mind. Oxford University Press, Oxford

Graves R (2000) Goodbye to All That. Revised edn. Penguin, London

Griffin J (1986) Well-being: its meaning, measurement, and moral importance. Clarendon Press, Oxford

Harari Y (2005) Martial illusions: war and disillusionment in twentieth-century and renaissance military memoirs. J Mil Hist 69:43-72

Harari Y (2008) The ultimate experience: battlefield revelations and the making of modern war culture, 1450 2000. Palgrave Macmillan, Basingstoke

Holmes R (1976) Shelley: the pursuit. Quartet, London

Hurka T (1993) Perfectionism. Oxford University Press, Oxford

Jones, D. 1937. In parenthesis: Seinnyessit e Gledyf ym Penn Mameu. London: Faber \& Faber

Jünger E (2003) In: Hoffman M (ed) Storm of steel trans, New edn. Allen Lane, London

Kendall T (ed) (2013) Poetry of the first world war: an anthology. Oxford University Press, Oxford

Kraut R (2007) What is good and why: the ethics of well-being. Harvard University Press, Cambridge MA

Lakoff G (1987) Women, fire, and dangerous things: what categories reveal about the mind. University of Chicago Press, Chicago

Leckey M (1999) Fiorucci Made Me Hardcore. Self-released. https://vimeo.com/5632791

Lessing D (1995) Under my skin: volume one of my autobiography, to 1949. Flamingo, London

Lockridge LS (1989) The ethics of romanticism. Cambridge University Press, Cambridge

MacIntyre A (2007) After Virtue: A Study in Moral Theory. $3^{\text {rd }}$ edn. Bloomsbury, London

Moorcroft Wilson J (2013) Siegfried Sassoon: Soldier, Poet, Lover, Friend. Duckworth, London

Nagel T (1979) The possibility of altruism. Princeton University Press, Princeton

Nietzsche F (1997) Schopenhauer as educator. In: Breazeale D (ed) R. J. Hollingdale trans. Untimely Meditations. Cambridge University Press, Cambridge, pp 125-194

Nietzsche, F. 2007. D. Large trans. Ecce Homo: How to Become What You Are. Oxford: Oxford University Press

Norton DL (1976) Personal destinies: a philosophy of ethical individualism. Princeton University Press, Princeton

Nussbaum MC, Sen A (eds) (1993) The quality of life. Oxford University Press, Oxford

O’Neill J (2008) Happiness and the good life. Environmental Values 17:125-144

Parfit D (1986) Reasons and Persons. Corrected edn. Oxford University Press, Oxford

Pascal, R. 1960. Design and truth in autobiography. London: Routledge \& Kegan Paul

Paul LA (2014) Transformative Experience. Oxford University Press, Oxford

Paul LA (2015) What you Can't expect when You're expecting. Res Philosophica 92:149-170

Rawls J (1999) A Theory of Justice. Revised edn. Harvard University Press, Cambridge MA

Reggio G, Director and producer (1982) Koyaanisqatsi. IRE

Rosati C (2013) The story of a life. Social Philosophy and Policy 30:21-50

Sacks O (1986) The lost mariner. In: The Man Who Mistook His Wife for a Hat. London: picador, pp 22-41

Sassoon S (1937) The complete memoirs of George Sherston. Faber \& Faber, London

Sassoon S (1938) The old century and seven more years. Faber \& Faber, London

Sassoon S (1942) The weald of youth. Faber \& Faber, London

Sassoon S (1945) Siegfried's journey, 1916-1920. Faber \& Faber, London

Sassoon S (1984) Collected poems 1908-1956. Faber \& Faber, London

Schechtman M (1996) The constitution of selves. Cornell University Press, Ithaca

Searle J (1983) Intentionality: an essay in the philosophy of mind. Cambridge University Press, Cambridge

Sheffield G (2001) Forgotten victory: the first world war: myths and realities. Headline, London

Sidgwick H (1981) The Methods of Ethics. $7^{\text {th }}$ edn, Indianapolis. Hackett

Slote M (1983) Goods and virtues. Clarendon Press, Oxford 
Spufford F (1996) I may be some time: ice and the English imagination. Faber \& Faber, London Sumner LW (1996) Welfare, happiness, and ethics. Clarendon Press, Oxford

Taylor C (1989) Sources of the self: the making of the modern identity. Harvard University Press, Cambridge MA Taylor C (1991) The ethics of authenticity. Harvard University Press, Cambridge MA

Tiberius V (2015) Prudential Value. In: Hirose I, Olson J (eds) The Oxford handbook of value theory. Oxford University Press, Oxford, pp 158-174

Velleman JD (2000) Well-Being and Time. In: The possibility of practical reason. Oxford University Press, Oxford, pp 56-84

Williams B (2002) Truth and truthfulness: an essay in genealogy. Princeton University Press, Princeton

Winter JM (1995) Sites of memory, sites of mourning: the great war in European cultural history. Cambridge University Press, Cambridge 